\title{
USF2 wt Allele
}

National Cancer Institute

\section{Source}

National Cancer Institute. USF2 wt Allele. NCI Thesaurus. Code C53119.

Human USF2 wild-type allele is located in the vicinity of $19 q 13$ and is approximately $11 \mathrm{~kb}$ in length. This allele, which encodes upstream stimulatory factor 2 protein, plays a role in the modulation of transcription. 